\title{
Effect of Pastor's Church Ministry on their Family Stability in Nairobi County, Kenya
}

\author{
Jaccobed W. Maina \\ School of Education and Social Sciences, \\ Kenya Methodist University, Kenya \\ Dr. Zipporah Kaaria (PhD) \\ Rev. Gregory Kivanguli \\ Department of Theology, Religious Studies and Counselling, \\ Kenya Methodist University. Kenya
}

\begin{abstract}
The family is an important place for individual mental growth. Pastors' families, however, experience ministry related challenges with potential ramifications on their family stability. The specific objectives were; To find out the extent to which pastors work as a preacher affects family stability in selected churches in Eastlands - Nairobi County, to establish the extent to which pastoral care work affects family stability, and to determine the extent to which church administration work affects family stability. The research was guided by the Structural Family Theory developed by Salvador Minuchin and Family Systems theory propounded by Murray Bowen. Descriptive survey design was used. The sample of 166 respondents comprised of pastors, pastors' spouses and adult children. Data were collected using a structured questionnaire and analyzed using descriptive statistical techniques. Hypotheses were tested using Spearman's rank correlation technique at $\mathrm{p}<.05$. The results showed that the relationship between preaching and family stability was not statistically significant. However, it was found that church administration and pastoral care had a significant negative correlation with family stability. It was recommended that the church needs to find ways of mitigating negative effects of church ministry by professionalizing its human resource systems and engaging professional counsellors for pastors and their families.
\end{abstract}

Keywords: Church, Ministry, Pastor, Family, Stability 


\section{Introduction}

A family affects the growth of every member, and plays an important role in the normal operation process of a social system. Therefore, family function is restricted by the characteristics of the family itself, and depends on the social demand (Dai \& Wang, 2015). According to Dai and Wang (2015), the concept of family stability can be divided into three dimensions: family intimacy, family adaptability and family communication. The family intimate degree refers to the relationship between family members (disengaged, separated, connected or enmeshed); family adaptability is the ability of family rules to cope with the external environmental pressure or the development of marriage; and family communication refers to the interaction between family members, which is important for the development of family intimacy and adaptability (Dai \& Wang, 2015).

According to McBride, Sedlacek, Baltazar, Matthews and Chelbegean (2013), pastoring is among the most trusted professions, with individuals and families turning to pastors for help in a wide variety of traumatic experiences. These demands frequently result in considerable difficulty in time boundaries. Congregants often expect their pastor to be available at all times. These time demands may result in the pastor being less available for their own family. Family stability among pastors' families is a neglected research area. It has been noted that pastors' families live under unique and significant pressures that may affect their family stability. Gauger and Christie (2013) argue that the ministry is perhaps the single most stressful and frustrating working profession, more than medical, legal, or political careers. They refer to statistics which say that $60 \%$ to $80 \%$ of those who enter the ministry will not still be in it 10 years later, and only a fraction will stay in it as a lifetime career. They reported one study which found that over $70 \%$ of pastors are so stressed and burned out that they regularly consider leaving the ministry (Gauger \& Christie, 2013).

A review of the literature on pastors' families suggest that such families are confronted by a chain of incidences: the families of pastors can be extremely strained, and this tension can have implications on their physical, emotional, mental, social, and spiritual health (Aulthouse, 2013). The influence of church ministry on pastors' family stability can be examined under three different dimensions namely: preaching, pastoral care and church administration. As preachers, pastors may feel the pressure to walk their talk because of the high expectation society puts on them as model families (Snodgrass, 2014). As a result, the pastor may transfer this expectation to members of his family who may not cope with the unrealistic expectations of the society and this can cause tension in the family which can destabilize the pastor's family (Hayes, 2010). This can especially contribute to frustrations to children especially when they feel that their parents' image is preserved at the 
expense of their personal life. It can thus be inferred that members of the pastors' family are not supposed to be themselves and this robs them of their freedom which can affect stability of their family. For example, when the child is not fully matured and able to cope up with the strains, the pastor's child may reject the ministry and even the family at extreme cases due to high expectations and long for a different life style.

The second dimension is pastoral care which involves provision of spiritual and psychological counselling to members of the congregation. Webb (2011) records that pastors often feel pressured by the need to minister to those who are hurting and need direction. Among congregants are those who need encouragement, comfort and advice on how to handle stressors in their lives including distress, diseases, family conflicts and work related stresses. According to Miles and Proeschold (2012) the number of family problems among pastors' families is on the rise despite the advantages and benefits that come with pastoral care. These exposures may affect the function of the pastor which can cause strain in the family, thereby affecting family stability.

The third dimension is church administration. According to Kleinplatz (2012), pastors should balance church administration with family life as achieving this balance mitigates against instability in the family. However, pastors can be engrossed into the demands of church administration that leaves them very little time to attend to the needs of members of their family. Pastors are often at the center of church administration activities including church development and investment, day-to-day running and operation of the church, development and implementation of church policies, staff and volunteer recruitment and training, and many more. All these can deprive pastors of the time they need to spend with their family and attend to family obligations.

\section{Statement of the Problem}

The stability of pastors' families has significant spill over effects on societal wellbeing because of not only the influential position pastors hold as church ministers in society but the multiple role they play as first responders and counsellors to many families in distress. Insights into how ministry affect the stability of pastors' families is therefore the first step towards mitigating any adverse effects on the overall wellbeing of the church.

While serving as a preacher has an exalting effect on pastors, society also has a high expectation on pastors' families which can exact undue pressure to the detriment of family stability. The nature of church ministry also involves a lot of pastoral care, sometimes at odd hours, which can drain the pastors' family resources. Pastors, as the head of their respective local churches, also undertake administrative functions which can compete with other family demands. This can be a source of family instability among pastors' families. 
Research evidence suggests that the number of family problems among pastors' families is on the rise despite the advantages and benefits that come with pastoral work (Miles \& Proeschold, 2012). However limited research attention has been directed at how pastors' church ministry affects the stability of the pastors' families. Previous researches and studies dealt with surveys and data from secondary sources on challenges the families of pastors face in general and across denominations within and outside Kenya but few, if any, have delved on the psychosocial effect of pastors' church ministry on their family stability. Therefore, this proposed study is expected to provide useful information on how church ministry affects pastors' family stability and the counselling interventions that can be used to help pastors balance between pastoral duties and family responsibilities.

\section{Objectives of the Study}

1. To find out the extent to which pastors work as a preacher affects family stability in selected churches in Eastlands, Nairobi County.

2. To establish the extent to which pastoral care work affects family stability in selected churches in Eastlands, Nairobi County.

3. To determine the extent to which church administration work affects family stability in selected churches in Eastlands, Nairobi County.

\section{Research Hypotheses}

$\mathrm{H}_{01} \quad$ There is no significant relationship between pastors' work as a preacher and their family stability.

$\mathrm{H}_{02}$ There is no significant relationship between pastoral care work and pastors' family stability.

$\mathrm{H}_{03}$ There is no significant relationship between church administration work and pastors' family stability.

\section{Literature Review}

\section{Effect of preaching work on family stability}

Preaching takes a significant part of the pastors' time and attention. The implication of this is that pastors must divide the remaining part of their time serving in different capacities while also attending to their family obligations. As a result, the pastor's wife is looked upon to support him in his ministry. Joynt and Dreyer (2013) assert that pastoral work leads to a 'two person, single career' situation where the spouse is often contributing resources without compensation. From the onset, pastor's wives are neither equipped nor motivated to take on the work of an assistant. Carroll (2006) concurs that pastors and their families face a wide range of challenges including work related time pressures and frequent relocations, family neglect, financial stress, lack of privacy in the family, emotional stress during crisis situations, lack of 
personal friend, high expectations and criticisms from the public and church members. This suggests that by definition, the pastors' family is set up to live a stressful life and families that fail to cope eventually disintegrate.

Kasomo (2010) examined the role of women in the church in Africa with specific reference to churches in Accra, Ghana and found that women play a dominant part behind the scenes yet without being appreciated. This means that being a pastor's spouse spells additional responsibility that affect their quality of life which is not found in most other careers. Often, the spouse plays the role of personal assistant to the pastor in church ministry including arranging meetings, helping with the pastor's travel arrangements and coordinating pastoral care on behalf of the pastor. These roles are rarely taken into consideration by the church and therefore, the implication of their role overload on family stability is potentially adverse. However, Mullins (2016) states that pastors' families endure because of pastor's profession as a preacher, thus do not affect the stability of their families.

Tension, fatigue and the pressure of excessive time demands can drain resources necessary for dealing with the normal responsibilities of family life. For instance, a study reported by Oney (2009) in the United States found that $80 \%$ of pastors believe that the pastoral work has affected their families negatively and $50 \%$ of pastors feel unable to meet the demands that are placed upon them. Because of their visibility and the place they hold in the church, society expects highly of pastors and their families. This means that church ministry work is a potential source of instability among pastors' families.

Samau and Schoeffel (2015) speculate that pastor's children are perhaps the most deeply affected of all due to a parent's work as a preacher. Most of them are reared in homes owned by the church and set aside for their parents' use. They are more likely to be involved in the church's activities than other church raised children. Aulthouse (2013), adds that pastor's family members are often treated as if they are different; children may be left out of peer activities, and spouses may feel unable to share feelings with those outside the family. This often than not affects their development, maturity and family bonding when they are not capable of coping with expectations of perfection (Samau \& Schoeffel, 2015). This means that just like the spouses of pastors, children also suffer from role ambiguity and role overload. However, it is not clear how these effects may affect family stability.

The pressure on pastor's children was briefly discussed by Ajibade (2017) in their study of church ministries in Nigeria. According to Ajibade (2017), this pressure emanates from ministry expectation, biblical expectation, parental expectations and societal expectations. Church ministry is regarded as a highly esteemed profession and the children's character should be above board and serve as role model and a standard for what an ideal kingdom child should look like. This is notwithstanding the fact that they do not have special 
abilities but rather, are ordinary children like their peers who have the freedom to be and behave the way normal children should conduct themselves.

Biblically, pastor's children are expected to be in submission with all reverence, children who are not accused of indulgence or insubordination. The natural output that pastors expect from their children is usually of high standards irrespective of whether their input is commensurate or not. They expect their children not to be the source of disgrace or embarrassment to the ministry without necessarily modelling the same character (Delaney \& Winters, 2013).

\section{Effect of pastoral care work on pastors' family stability}

Pastoral care involves interacting at an individual level with each congregant, counseling them and visiting them and their families when they are sick (Proeschold-Bell et al., 2015). It has been established from research on churches in the United States that pastors tend to put the needs of others before their own, are sedentary, spend an average of four evenings a week away from home, and work 50 or more hours a week (Cocklin, 2013). The pastors therefore leave little time to take care of themselves and their families and this could lead to family dysfunction and instability.

According to Gauger and Christie (2013), while administering pastoral care, pastors also experience more negative interaction from regular members although they receive more emotional support from fellow ministers and leaders. These negative interactions with the congregation exert a variety of deleterious effects on pastors, including depression. From this perspective, it can be inferred that the more demanding the congregation, the lower the pastor's sense of well-being and life satisfaction and the lower the family stability. The negative interactions may deplete the emotional resources the pastor's spouse and children need to function effectively as members of the pastor's family and this has the potential to affect the stability of their families.

Joynt and Dreyer (2013) associate the work-life of pastors as characterized by stress and burnout as they are confronted with the emotional demands that are tied in with ministry work with intensive pastoral care. Findings of their study indicate that pastors who scored high on the index of emotional exhaustion felt their marriage and family life were negatively affected by the ministry, found it hard to deal with difficult and critical church service attenders or members, found it hard to make and keep close friends, felt high stress in their vocation, and often thought of leaving ministry work. From these arguments, it can be speculated that most pastors lack clear boundaries between their ministry work and family life.

In Nigeria, Abosede (2014) in his research described the pastors in Nigeria as fully engaged in teaching and preaching, visiting, counselling and encouraging. They also do administration and engage in social ministry in 
order to meet the holistic needs of their parishioners. However, the pastor is also a family man who must take care of his family and see to it that they are built up in the way of the Lord. The society does not want to know whether his wife and family receives ministerial training or not, they expect them to be godly and behave well. His pastoral ministry is not confined to the four corners of his Church. He is a public figure and consequently must make every effort to protect his integrity in the discharge of his duties. All these expectations add to the pressure pastor's face in their endeavour to balance the needs of church ministry and their obligations as family men.

According to Haynes (2014), problems in developing and maintaining social relationships lead over time to increased social isolation and loneliness, which in turn are risk factors associated with both burnout and behavioural addiction among pastors and their spouses. When intimacy needs are not being met, when there is a persistent sense that one is not understood by another person at the deepest levels of the self, it is not uncommon that problematic sexual behaviour emerges, as a dysfunctional effort to enhance social connectedness. Almost forty percent of spouses polled by Hayes (2010) said they have had an extra-marital affair since beginning their ministry. Seventy percent of pastors do not have a close friend, confidant, or mentor (Cocklin, 2013). Such affairs are found to emanate from the nature of the pastors work and this is a recipe for family instability.

A study comparing stress among pastors' wives and ordinary congregants' wives was undertaken by Nandasaba (2011) in Kenya. According Nandasaba (2011) the findings revealed that although pastors' wives exhibited various stress related symptoms just like any ordinary woman, they nevertheless suffered higher levels of stress than ordinary members' spouses. This was due to financial and family matters, loneliness, people's high expectations and demands, lack of privacy in homes and poor self-image. From Nandasaba's study, it can be inferred that the work-life balance of pastors is often characterized by role ambiguity and lack of clear boundaries.

Cocklin (2013) recommended to the church dealing with pastoral care, losing the strong-man mentality, and setting realistic expectations and resiliency training for pastors and spouses. This means that programs should be in place to equip pastors with the necessary skills to be effective ministers of the word and of their families. Haynes (2014) qualifies these perspectives with the observation that when asked about coping with stress, the pastors in his study identified engagement in healthy behaviours such as hobbies, recreational activities, maintenance of family relationships, and spiritual disciplines as broadly effective strategies. Church members may also take an active role in providing support by including pastors' families in community events, providing regular positive feedback or affirmation, and offering 
specific resources to support pastors' family vacations and their participation in organized leisure activities.

\section{Church administration work and family stability}

Another role of the pastor as discussed by Proeschold-Bell et al. (2015) is that of church administration including supervising church staff, committees and overseeing construction of church buildings and budgets. Work environment factors common to most pastors include regularly dealing with major life transitions (such as funerals, conversions, family crises and personal traumas), repetitive tasks, coping with the daily operations of organizations (meetings, budgets, and financial pressures), and theological disagreements (Reimer, 2010). Consequently, pastors work in environments in which there is "too much work, too little support, rigid work schedules, difficult parishioners, being 'on call' twenty-four hours a day, seven days a week, excessive bureaucracy, and unhelpful and often irrelevant denominational structures (Gauger \& Christie, 2013). This calls for churches to create the work environment that will allow the pastor to have a healthy balance between ministry work and family life.

The work-life of pastors also often involve organizing and supporting activities within their denomination and collaborating with community organizations to administer social justice (Proeschold-Bell et al., 2015). Based on a study of pastor's social justice role in New Orleans, Abernethy, Grannum, Gordon, Williamson, and Currier (2016) noted that pastors frequently stand in the gap to attend to the multifaceted needs of impoverished and underserved individuals, particularly in the context of natural disasters or human-engineered injustice. In the process, the needs of their own families are often left unattended and this potentially affect the stability of their families.

The effect of church administration on family function has been found to vary by gender. Gauger and Christie (2013) raise the point that what one pastor may regard as stressful may be considered by another as normal and manageable. Payne (2017) identified the "calling" theme as prominent among pastors serving urban resource-poor areas. From these perspectives, it can be inferred that there exist potential differences in the relationship between pastors' church ministry and their family stability.

In Africa, Razafindrakoto (2014) explored the issue of pastor's remuneration among Baptist churches in Antananarivo, Madagascar. The study involved an interview with seven pastors and church members in charge of finance. The study found that pastors were not supported as they should have been, and that their remuneration was not commensurate to the work they performed. Further, despite the work overload that confronts pastors' families, the income of the pastor's spouse is also a determining factor of pastoral 
remuneration such that, when the church knows that its pastor has other sources of income, such as from his wife, the pastor would receive lower remuneration. This puts pastors' families in financial strain that affects their family stability.

Gauger and Christie (2013) quote one counselor who confessed that pastor's wives are the angriest people he sees. Their study of different denominational churches in Florida, California found that $80 \%$ of pastors' spouses feel their spouse is overworked, $80 \%$ of pastor' wives feel left out and unappreciated by the church members, $80 \%$ of pastors' spouses wish their spouse would choose another profession, $80 \%$ of pastors' wives feel pressure to do things and be something in the church that they are really not. The majority of pastor's wives that they surveyed said that the most destructive event that occurred in their marriage and family was the day they entered the ministry (Stitt, 2012).

A study was done by Cocklin in Findlay, Ohio in 2013 on the importance of pastors' resilience in facing the demands of ministry. Cocklin's 2013 research was based on an electronic survey of fifty-two former pastors and one hundred and twenty-four pastors who were still active with fifteen or more years of pastoral experience. The main conclusions drawn from the study was that former pastors did not have the appropriate resources available to them to successfully deal with challenges, lacked accountability, felt isolated, did not manage conflict well and felt unprepared in practical ministry. This provides opportunity for psychosocial intervention. Cocklin (2013) identified certain social and psychological characteristics for effective family stability. They included commitment, appreciation, time together, communication, faith and values, and coping skills as the healthy traits in families.

Gauger and Christie (2013) acknowledge that intrinsic in church ministry is the constant challenge of maintaining boundaries between one's administrative workload and one's personal life. In their view, stress for pastors and their families is inevitably caused when the pastor fails to establish boundaries, or when the church demands that the boundaries be changed for its purposes. This happens when the pastor brings work home, dumps on the spouse the frustration of the events of the day, continually answers the phone during meals, and/or fails to carve out time for family. Challenges to boundary maintenance occur when the church matters intrude into time that is set aside for the family or members fail to respect the privacy of the pastor's family.

\section{Research Methodology}

Descriptive survey design was used for this study. Weiten (2012) explains this research design as an approach which allows researchers to describe patterns of behaviour and establish associations between variables. The study targeted selected churches registered with the National Council of Churches of Kenya in Nairobi. In total, there are 29 churches registered with 
this body (NCCK, 2017).The six selected churches comprised of mainstream and Pentecostal churches.

Purposive sampling technique was used to select pastors' families to be included in the sample. According to Mugenda \& Mugenda, (2008), purposive sampling is a sampling technique that allows a researcher to use cases that have the required information with respect to the objectives of the study. From each family, the pastor, the spouse and one adult child of either gender was selected to participate. The church leadership assisted in identifying the participants for this study.

\section{Findings and Discussions}

The first objective was to investigate the extent to which pastors' work as a preacher affects family stability. The findings in Table 1(a) indicate that there was no statistically significant correlation between preaching work and family stability $(r=.075, p>.05, N=64)$. This means that the stability of pastors' family could not be linked to pastors' preaching work from the perspective of the pastor. This finding agrees with the analysis by Mullins (2016) that pastors' families endure because of pastor's profession as a preacher, thus do not affect the stability of their families. This finding may be explained by the fact that the demand that preaching work puts on the pastor's family is limited to a few days in a week - typically a Sunday, thus leaving the pastor for the rest of the week to attend to the family. In addition, in most of the cases, pastors are often accompanied to church by members of their family, which makes the pastor almost always present in the lives of family members. In such an environment, the potential negative implications of ministry work on family stability are mitigated.

Table 1(a): Correlation between pastors' views on preaching work and family stability

\begin{tabular}{|c|c|c|c|c|}
\hline \multicolumn{3}{|c|}{ Spearman's rho } & 1 & 2 \\
\hline & \multirow{3}{*}{ Family stability } & Correlation Coefficient & 1.000 & \\
\hline & & Sig. (2-tailed) & 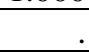 & \\
\hline & & $\mathrm{N}$ & 64 & \\
\hline \multirow{3}{*}{\multicolumn{2}{|c|}{ 2. Preaching work }} & Correlation Coefficient & .075 & 1.000 \\
\hline & & Sig. (2-tailed) & .553 & \\
\hline & & $\mathrm{N}$ & 64 & 64 \\
\hline
\end{tabular}

Table 1(b) shows no statistically significant relationship between preaching work and family stability ( $\mathrm{r}=-.060, \mathrm{p}>.05, \mathrm{~N}=47)$. It can thus be inferred that there was no association between family stability and preaching work based on the views of pastors' spouses. The finding contradicts Kasomo's (2010) implied observation that pastors' spouses were affected by pastor's role as a preacher by making unappreciated contributions to the pastor's effectiveness hence affecting family stability. The spouse is expected to help the pastor in the ministry because they are in this together. If both are 
in the ministry together, this will positively affect the church and role of the pastor. It is typical that a woman needs love and acceptance and the male needs respect. Discovering ways to validate these will lead to a healthier ministry and home and maintain family stability.

Table 1(a): Correlation between spouses' views on preaching work and family stability

\begin{tabular}{|c|c|c|c|c|}
\hline \multicolumn{3}{|c|}{ Spearman's rho } & 1 & 2 \\
\hline \multirow{3}{*}{\multicolumn{2}{|c|}{ 1. Family stability }} & Correlation Coefficient & 1.000 & \\
\hline & & Sig. (2-tailed) & . & \\
\hline & & $\mathrm{N}$ & 47 & \\
\hline \multirow{3}{*}{\multicolumn{2}{|c|}{ 2. Preaching work }} & Correlation Coefficient & -.060 & 1.000 \\
\hline & & Sig. (2-tailed) & .694 & \\
\hline & & $\mathrm{N}$ & 47 & 47 \\
\hline
\end{tabular}

Table 1(c) indicates that, according to pastors' children's views there was no statistically significant relationship between preaching work and family stability $(\mathrm{r}=.260, \mathrm{p}>.05, \mathrm{~N}=55)$. This means that family stability was not significantly affected by pastors' work as a preacher based on the views of children of pastors' families. This finding contradicts the discussion by Ajibade (2017) suggesting that pastor's preaching work negatively affected their children leading to family stability issues. This may be explained by the fact that most of the children under study perhaps adjusted well to their parent's profession and were able to cope without causing family instability. The null hypothesis that stated that there is no relationship between preaching work and family stability was therefore not rejected, meaning that preaching work had no influence on the stability of pastors' families.

Table 1(c): Correlation between children's views on preaching work and family stability

\begin{tabular}{|c|c|c|c|}
\hline \multicolumn{2}{|c|}{ Spearman's rho } & 1 & 2 \\
\hline \multirow{3}{*}{ 1. Family stability } & Correlation Coefficient & 1.000 & \\
\hline & Sig. (2-tailed) & & \\
\hline & $\mathrm{N}$ & 55 & \\
\hline \multirow{3}{*}{ 2. Preaching work } & Correlation Coefficient & .260 & 1.000 \\
\hline & Sig. (2-tailed) & .055 & \\
\hline & $\mathrm{N}$ & 55 & 55 \\
\hline
\end{tabular}

The second objective was to investigate the extent to which pastoral care work affects family stability. Table 2(a) indicates that the results of data analysis of pastors' views showed a statistically significant negative correlation between pastoral care and family stability $(r=-.300, \mathrm{p}<.05, \mathrm{~N}=64)$. The findings suggest that the relationship between pastoral care and the stability of pastors' families was statistically significant. This means that family stability decreased with increase in pastoral care from the perspectives of the pastors. This implies that the pastors themselves perceived that their involvement in pastoral care negatively impacted on their family stability. It can be inferred that pastoral care work negatively affected the stability of 
pastors' families. This corroborates with the observation made by Gauger and Christie (2013) that pastors often experience negative interaction from regular members while administering pastoral care with negative implications on their own emotional wellbeing and by extension, the stability of their families.

Table 2(a): Correlation between pastors' views on pastoral care work and family stability

\begin{tabular}{|c|c|c|c|c|}
\hline \multicolumn{3}{|c|}{ Spearman's rho } & 1 & 2 \\
\hline \multirow{3}{*}{\multicolumn{2}{|c|}{ 1. Family stability }} & Correlation Coefficient & 1.000 & \\
\hline & & Sig. (2-tailed) & 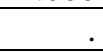 & \\
\hline & & $\mathrm{N}$ & 64 & \\
\hline \multirow{3}{*}{\multicolumn{2}{|c|}{ 2. Pastoral care work }} & Correlation Coefficient & $-.300^{*}$ & 1.000 \\
\hline & & Sig. (2-tailed) & .016 & \\
\hline & & $\mathrm{N}$ & 64 & 64 \\
\hline
\end{tabular}

*. Correlation is significant at the 0.05 level (2-tailed).

Table 2(b) shows that a significant negative correlation was obtained between pastoral care and family stability from the perspective of spouses $(\mathrm{r}=-$ $.371, \mathrm{p}<.05, \mathrm{~N}=47$ ). This means that pastors' spouses perceived that family stability decreased with increased involvement in pastoral care by the pastor. The finding resonates with those by Abernethy et al. (2016) that the demands of pastoral care place pastors at risk of stress-related problems that may diminish their capacity to attend to their families. The finding is echoed in a study by Joynt and Dreyer (2013) which reported that pastors who scored high on the index of emotional exhaustion due to pastoral care felt their marriage and family life were negatively affected by the ministry.

Table 2(b): Correlation between spouses' views on pastoral care work and family stability

\begin{tabular}{|c|c|c|c|}
\hline \multicolumn{2}{|c|}{ Spearman's rho } & 1 & 2 \\
\hline \multirow{3}{*}{ 1. Family stability } & Correlation Coefficient & 1.000 & \\
\hline & Sig. (2-tailed) & & \\
\hline & $\mathrm{N}$ & 47 & \\
\hline \multirow{3}{*}{ 2. Pastoral care work } & Correlation Coefficient & $-.371^{*}$ & 1.000 \\
\hline & Sig. (2-tailed) & .012 & \\
\hline & $\mathrm{N}$ & 47 & 47 \\
\hline
\end{tabular}

*. Correlation is significant at the 0.05 level (2-tailed).

Table 2(c) indicates that the results of data analysis of pastors' children's views showed a statistically significant negative correlation between pastoral care and family stability $(\mathrm{r}=-.411, \mathrm{p}<.01, \mathrm{~N}=55)$. This implies that, according to pastors' children, the level of family stability decreased the more the pastor got involved in pastoral care. The correlation coefficients reveal that the highest negative correlation between pastoral care and family stability was obtained from children's responses, suggesting that pastoral care had a greater impact on the children as compared to their parents. A higher negative coefficient was also obtained from responses of pastors' spouses, suggesting that besides children, spouses of pastors were next in rank of members of the pastors' family bearing the brunt of the pastors' involvement in pastoral care. 
This agrees with Samau and Schoeffel's (2015) speculation that pastor's children are perhaps the most deeply affected of all due to their parent's profession as a pastor. The null hypothesis that stated that there is no relationship between pastoral care work and family stability was rejected, implying that pastoral care negatively affected the stability of pastors' families.

Table 2(c): Correlation between children's views on pastoral care work and family stability

\begin{tabular}{|c|c|c|c|c|}
\hline \multicolumn{3}{|c|}{ Spearman's rho } & 1 & 2 \\
\hline & \multirow{3}{*}{ Family stability } & Correlation Coefficient & 1.000 & \\
\hline & & Sig. (2-tailed) & & \\
\hline & & $\mathrm{N}$ & 55 & \\
\hline \multirow{3}{*}{\multicolumn{2}{|c|}{ Pastoral care work }} & Correlation Coefficient & $-.411^{* *}$ & 1.000 \\
\hline & & Sig. (2-tailed) & .002 & \\
\hline & & $\mathrm{N}$ & 55 & 55 \\
\hline
\end{tabular}

**. Correlation is significant at the 0.01 level (2-tailed).

The third objective was to determine the extent to which church administration work affects family stability. Table 3(a) indicates that the results of data analysis of pastors' views showed no statistically significant correlation between church administration and family stability $(r=-.005, p>.05$, $\mathrm{N}=64$ ). This means that family stability is not affected by pastors' involvement in church administration from the perspective of the pastors. This may be explained by the fact that the pastors not only see their ministry work as a calling but accept church administration as part of the expectation of the profession. The results agree with Payne (2017) who identified the "calling" theme as prominent among pastors interviewed.

Table 3(a): Correlation between pastors' views on church administration work and family stability

\begin{tabular}{|c|c|c|c|c|}
\hline \multicolumn{3}{|c|}{ Spearman's rho } & 1 & 2 \\
\hline & \multirow{3}{*}{ Family stability } & Correlation Coefficient & 1.000 & \\
\hline & & Sig. (2-tailed) & . & \\
\hline & & $\mathrm{N}$ & 64 & \\
\hline & \multirow{3}{*}{ Church administration work } & Correlation Coefficient & -.005 & 1.000 \\
\hline & & Sig. (2-tailed) & .970 & \\
\hline & & $\mathrm{N}$ & 64 & 64 \\
\hline
\end{tabular}

Table 3(b) also indicates that the results of data analysis of views of pastors' spouses showed no statistically significant correlation between church administration and family stability $(\mathrm{r}=-.052, \mathrm{p}>.05, \mathrm{~N}=47)$. This means that the pastor's involvement in church administration does not affect family stability from the perspective of their spouses. This is potentially due to the fact that spouses of pastors were able to set limits with regards to expectation of their involvement in administration. This is in line with past studies by Gauger and Christie (2013) who found that clergy spouses, especially female spouses, did not have difficulty setting limits and developing coping skills than their male 
counterparts. This means that family stability was not affected by church administration from the perspective of pastors' spouses.

Table 3(b): Correlation between spouses' views on church administration work and family stability

\begin{tabular}{|c|c|c|c|c|}
\hline \multicolumn{3}{|c|}{ Spearman's rho } & 1 & 2 \\
\hline \multirow{3}{*}{\multicolumn{2}{|c|}{ 1. Family stability }} & Correlation Coefficient & 1.000 & \\
\hline & & Sig. (2-tailed) & 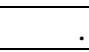 & \\
\hline & & $\mathrm{N}$ & 47 & \\
\hline \multirow{3}{*}{\multicolumn{2}{|c|}{ 2. Church administration work }} & Correlation Coefficient & -.052 & 1.000 \\
\hline & & Sig. (2-tailed) & .733 & \\
\hline & & $\mathrm{N}$ & 47 & 47 \\
\hline
\end{tabular}

Table 3(c) indicates that the results of data analysis of pastors' children's views revealed the existence of a statistically significant negative correlation between Pastors church administration work and family stability $(\mathrm{r}=-.281, \mathrm{p}<.05, \mathrm{~N}=55)$. The findings suggest that the relationship between preaching work and the stability of pastors' families was statistically significant from the perspectives of children. Church administration work had a negative influence on the stability of pastors' families as far as children were concerned. The null hypothesis that stated that there is no relationship between church administration work and family stability was thus rejected.

Table 3(c): Correlation between children's views on church administration work and family stability

\begin{tabular}{|c|c|c|c|c|}
\hline \multicolumn{3}{|c|}{ Spearman's rho } & 1 & 2 \\
\hline & \multirow{3}{*}{ Family stability } & Correlation Coefficient & 1.000 & \\
\hline & & Sig. (2-tailed) & & \\
\hline & & $\mathrm{N}$ & 55 & \\
\hline & \multirow{3}{*}{ Church administration work } & Correlation Coefficient & $-.281^{*}$ & 1.000 \\
\hline & & Sig. (2-tailed) & .038 & \\
\hline & & $\mathrm{N}$ & 55 & 55 \\
\hline
\end{tabular}

*. Correlation is significant at the 0.05 level (2-tailed).

\section{Conclusion}

The study found that most of the pastors in church ministry were males and therefore most of the spouses are female. This means that as the male pastors are attending to ministry work demands, their female spouses are attending to the family matters. This may have helped in boosting pastor's family stability since women are socialized to be nurturers. Majority of the respondents across the board agreed that there was family stability in their family. However, perception of family stability among members of the pastor's family differed from one member of the family to another. Pastors had the most favourable evaluation of stability in the family while spouses had the least favourable perception of stability in the family. Pastoral care work had a negative influence on the pastor's family stability. Pastoral care sups a lot of the pastor's time and energy resulting in limited time spent with the family. 
This may negatively affect the pastor's psychological wellness and cause burnout.

Pastors church administration work was noted to negatively affect the pastor's children. These children assist in administrative activities such as expert support to church groups, playing church music instruments and service projections and sound systems among others. It appears from the responses and opinions given by all the respondents that the pastor's family would benefit from professional counselling to cope with the issues leading to family instability. This means that promoting healthy and positive family interaction processes may contribute greatly to stability in the pastor's family. The respondents suggested that Pastor's families can be supported by giving the pastor uninterrupted time off, sensitization of pastors and congregants, sponsored holiday, employing assistants, better pay and more appreciation.

\section{References:}

1. Abernethy, A. D., Grannum, G. D., Gordon, C. L., Williamson, R. C., \& Currier, J. C. (2016). The pastors' empowerment program: A resilience education intervention to prevent clergy burnout. Spirituality in Clinical Practice, 3(3), 175-186.

2. Ajibade, E. A. (2017). Towards and ethical life and conduct in pastors' children. Retrieved on $5^{\text {th }}$ February 2017 from http://www.academia.edu/30162785/Towards_An_Ethical_Life_and_ Conduct_in_Pastors_Children.pdf

3. Aulthouse, M. E. (2013). Clergy families: The helpless forgottens' cry for help answered through reality therapy. Retrieved on $27^{\text {th }}$ January 2017 from https://www.counseling.org/docs/defaultsource/vistas/clergy-families-the-helpless-forgottens-cry-forhelp.pdf?sfvrsn=11

4. Carroll, Jackson W. (2006). God's Potters: Pastoral Leadership and the Shaping of Congregations. Grand Rapids, MI: William B. Eerdman's Publishing Company.

5. Cocklin, J. W. (2013). Pastoral resilience. Diss. Winebrenner Theological Seminary.

6. Dai, L. \& Wang, L. (2015). Review of family functioning. Open Journal of Social Sciences, 3(1), 134-141.

7. Delaney, J. J. \& Winters, J. W. (2013). Sinners or saints? Preachers' kids and risky health behaviors. Retrieved on $5^{\text {th }}$ February 2017 from http://ftp.iza.org/dp7434.pdf

8. Eriksen, A. (2012). The pastor and the prophetess: an analysis of gender and Christianity in Vanuatu. Journal of the Royal Anthropological Institute, 18(1), 103-122. 
9. Gauger, R. \& Christie, L. (2013). Clergy stress and depression. Retrieved on $2^{\text {nd }}$ February 2017 from https://www.pdresources.org/uploads/course/f1b78.pdf

10. Hayes, E. C. (2010). Differences in marital quality between full-time and bivocational pastors in the church of the Nazarene. Kansas State University. Retrieved on $10^{\text {th }}$ August 2018 from http://citeseerx.ist.psu.edu/viewdoc/download?doi

11. Haynes, W. C. (2014). Behavioural addictions in ministry. Programs for Psychology \& Religion. Retrieved on $3^{\text {rd }}$ February 2017 from http://www.slbmi.com/wp-content/uploads/2014/02/2014-WinterUpdate-News.pdf

12. Joynt, S. \& Dreyer, Y. (2013). Exodus of clergy: A practical theological grounded theory exploration of Hatfield Training Centre trained pastors. Retrieved on $2^{\text {nd }}$ February 2017 from http://www.hts.org.za/index.php/HTS/article/view/1940/3673

13. Kasomo, D. (2010). The role of women in the church in Africa. International Journal of Sociology and Anthropology, 2(6), 126-139.

14. Kenya National Bureau of Statistics (2017). 2009 Kenya Population and Housing Census, Nairobi: KNBS.

15. Kleinplatz, P.J. (2012).Sex Therapy. London: Routledge press.

16. McBride, D. C., Sedlacek, D., Baltazar, A., Matthews, L., \&Chelbegean, R. (2013). Family bonding and family dinners. Retrieved on $27^{\text {th }}$ January 2017 from http://digitalcommons.andrews.edu/cgi/viewcontent.cgi? article=1002 \&context=behavioral-pubs

17. Miles, A., \&Proeschold-Bell, R.J., (2012).Overcoming the Challenges of Pastoral Work. Peer Support Groups and Mental Distress among United Methodist Church Clergy. Sociology of Religion: A Quarterly Review.

18. Mugenda, O. M., \& Mugenda, A. G. (2008), Research Methods: Quantitative \& Qualitative Approaches. Nairobi: Acts Press.

19. Mullins, D. F. (2016). The effect of religion on enduring marriages. Social Sciences, 5(24), 1-14.

20. Nandasaba, T. L. (2011). Determination of effects of stress to pastor's wives on church ministries performance: A case of Bungoma South District. Retrieved on $27^{\text {th }}$ January 2017 from https://www.sats.edu.za/userfiles/A\%20case\%20of\%20Bungoma\%20 South\%20District.pdf

21. Oney, M. (2009). Ancient answers for developing modern-day clergy. Journal of Biblical Perspectives in Leadership, 2(2), 135-141.

22. Payne, J. S. (2017). "It's Kind of a Dichotomy": Thoughts Related to Calling and Purpose from Pastors Working and Counseling in Urban 
Resource-Poor Communities. Journal of Religious Health, 56(4), 1419-1435.

23. Proeschold-Bell, R. J., Eisenberg, A., Adams, C., Smith, B., Legrand, S., \& Wilk, A. (2015). The glory of god is a human being fully alive: Predictors of positive versus negative mental health among clergy. Journal for the scientific study of religion, 54(4), 702-721.

24. Reimer, S. (2010). Pastoral well-being: Findings from the Canadian Evangelical Churches study. Church \& Faith Trends, 3(2), 1-17.

25. Samau, B. \& Schoeffel, P. (2015). Pastors' daughters: Boundary ambiguity or the fishbowl effect? The Journal of Samoan Studies, 5(1), 88-96.

26. Snodgrass, J. (2014). Implications for pastoral counselling: Pastoral counselling journal, 63(3), 307-317.

27. Stitt, R.C. (2012). Imagine This. Xulon Press. ISBN 1622303407 , 9781622303403.

28. Stuart, A. (2015). Right to freedom of religion: A gendered difference. Journal of Gender and Power, 3(1), 25-66.

29. Webb, L.E. (2011). Crisis Counselling in the congregation. Nashville: Abingdon Press.

30. Weiten, W. (2012). Psychology: Themes and variations (8th ed.). Belmont, CA: Thomson Higher Education 